\title{
Products from mammoth Tusk in Yakutia in the 18th century (based on the materials of funerary monuments)
}

\author{
Aleksandra Prokopieva*, and Aytalina Sleptsova \\ Institute for Humanities Research and Indigenous Studies of the North of the RAS, 1, Petrovskogo St., Yakutsk, 677027, Russia
}

\begin{abstract}
The article is devoted to the study of products made from mammoth Tusk in Yakut burials of the 18th century. The work is based on literary and archival as well as on the collections of the museums. Analysis of products made from mammoth Tusk showed that they were not widely distributed among the Yakuts. This could be due to the fact that in the religious beliefs of the peoples of Yakutia the mammoth had a negative colour. Two movements of carving from a mammoth Tusk in the 18th century were revealed. The first movement was based on the traditions and techniques of local carving, and the second one was based on imitation of the Northern Russian school.
\end{abstract}

\section{Introduction}

Mammoth mining, import and export of raw materials from Russia and the manufacture of tusk products are becoming topical issues in the Arctic zone of Russia and Yakutia in particular. Both practical and theoretical aspects of this problem are being discussed. One of the interesting topics is the question: how traditional and primordial is the extraction of mammoth tusk and the production of household and artistic products from it? When discussing this topic in the context of the Yakut culture, they often turn to ethnographic materials and decorative and applied art, often without including archaeological research data in the source database. Meanwhile, at the moment, more than 300 funerary monuments dating from the 17th-18th centuries have been studied. Analysis of the accompanying inventory of the burials showed that among a large number of wooden, metal and bone products there are objects made of mammoth tusk. We assume that the number and nature of the products from the burials, the technique and quality of execution may indicate the level of mastering of the material by local craftsmen.

\section{Materials and methods}

According to R. I. Bravina, $69 \%$ of the total number of ground burials of the $15^{\text {th }}$ - early 19 th centuries. In Yakutia, there are items of accompanying inventory. They are more common in male and female burials (78\% and $68 \%$, respectively), less common in children's burials $(57 \%)$ [1 p. 99]. The set of items of accompanying inventory usually consisted of a suit, personal and household items, hunting tools and weapons, horse equipment, religious items and funeral food. According to the composition of the inventory, the material and the quality of its execution, it is possible to make assumptions about the status of the buried person, his occupation and professional affiliation. To identify items made of mammoth tusk in the burials, we studied museum collections (Yakut State United Museum of History and Culture of the Peoples of the North named after Em. Yaroslavsky, Museum of Archeology, Ethnography and Higher School of NEFU), archival materials (field reports from the Scientific and Branch Archive of the Institute of Archaeology of the Russian Academy of Sciences, diaries, protocols of opening graves from the funds of the National Archive of the RS (Ya)) and published literature. As a result, the discovery of 14 items from the mammoth tusk in 13 burials from the total number of funerary monuments dating from the 17th-18th centuries was recorded and explored by archaeologists. The selection is based on the availability of an accurate definition of the material of manufacture of the item. All items are personal items and include the following items: combs, pipe heads, cane heads, spoons, belt buckle, and two sticks of unknown purpose. In the course of studying the museum collections, we found that not all the items were preserved in the museum collections, some of them are known only from the reports of researchers.

\section{Results}

\subsection{Hairbrush and combs}

Hair combs in many cultures were endowed with symbolic symbols associated with the magic of hair [2 $\mathrm{p}$. 147]. At the moment, it is difficult to say whether they carried remarkable symbols in the context of the funeral rite of the Yakuts of the 17th-18th centuries, but wooden and bone combs were found in male and female burials. Among them, the combs from the mammoth task in the amount of 5 specimens are highlighted. The combs were

*Corresponding author:_aleksandra.pkkyyha@gmail.com 
found in the burials of Yelets I of the Megino-Kangalas district, Shaman Tree III of the Churapchinsky district [3 p. 102-103], Sangar of the Kobyai district [4 p. 73], Batyyalakh I and Koeboeng of Olenek district [5]. All combs are frame combs (the outside teeth are wider) of the bilateral type. The ridges have a trapezoidal shape, where the upper narrower part has rare large teeth, and the lower wider part has frequent small ones. The size of the combs varies from 6 to $7.5 \mathrm{~cm}$ in height, with the widest part from $6.6 \mathrm{~cm}$ to $7.5 \mathrm{~cm}$; in the narrowest part from $6 \mathrm{~cm}$ to $7.2 \mathrm{~cm}$. The number of large teeth is $18-20$ pieces; and that small teeth are up to 60 pieces. Marking lines are drawn on the surface of the products, sometimes serving as decoration (Shaman Tree I). At the comb from the burial of Yelets I, the sides have figured faces, decorated with recesses and notches. Judging by the materials of the Alazey and Stadukhinsky prisons, these combs are of Russian origin [6, p. 46-48]. This is also evidenced by the Siberian materials [7]. Apparently, under the influence of Russian traditions, similar doublesided combs were common in the Yakut culture of the 18th-19th centuries. It should be noted that the stories related to the semantic status of combs in the Yakut culture are borrowings from Russian culture [8, p. 217].

The topography of the combs inside the coffin is only known in three cases. In the partially destroyed burial of Sangar in the Kobyai district, a comb was found inside a birch vessel located at the feet of the buried man. Inside the vessel we placed scissors and a copper ring in addition to the comb. In the rich burial of Elecha $I$ in the Megino-Kangalas district, a traveling bag with a large amount of contents was found at the feet of the buried man. Among other things. It contained a wooden box for the storage of handicrafts, inside of which there were a birch mound, pieces of fur, white and black beads on a thread, a metal thimble and a mammoth tusk comb. In this context, it is likely that the comb was not used as a hygiene item, but as a tool for brushing tendon threads or horsehair. In the burial of Shamansky III in the Churapchinsky region, a comb was found on the left side of the thorax of the buried. The comb was in a wooden case and, judging by the tissue print on the surface of the case, was placed inside the caftan. According to the anthropological materials and accompanying equipment, all the burials with the combs in question were female.

\subsection{The heads of smoking pipes}

Smoking pipes, common on the territory of Yakutia of the 18th-19th centuries, are composite: a wooden chub made of two halves, a separate metal or bone head, a leather belt for winding the chubuk. In the ethnographic literature, these pipes are known as "belt pipes" and according to the typology of A.V. Shapovalov, they belong to the 4th or "American" type of smoking pipes in Siberia [9]. In the Yakut burials of the 18th century, pipes with a metal head are most often found. Mammoth bone heads were found in three burials: Shaman Tree I and III in Churapchinsky district and Ordegen I in Nyurbinsky district. All products are of the same type and are similar to metal ones, consisting of a bowl and a wide base - a leg. The height is $2.3-3.2 \mathrm{~cm}$, the diameter of the bowl is $3.5-4.5 \mathrm{~cm}$. The bowls are sculpturally carved and decorated to varying degrees with a carved pattern consisting of simple geometric shapes: lines (Ordegen I), dots and arched motifs (Shaman Tree I). The most elegant and delicate carving on the bowl from the group burial is the Shaman Tree I [3, p. 95]. The upper part of the body of the bowl is decorated with a line of a number of points, under it there are two girdles of two straight parallel lines. Immediately below the second girdle, closer to the bottom, the bowl is decorated with a repeating arched ornament with descending sprouts in the technique of relief carving. In general, decorative motifs and techniques are characteristic of Yakut carving of the 18th century, but the combination of smooth and relief carving in one product is not typical for the studied period. As with the metal-headed tubes, the tubes in question were found in the boot tops of the buried men.

\subsection{A clasp}

A mammoth tusk clasp was found in the male burial of Ordegen II of the Nurbin district. On the burial there was a caftan with asymmetrical shaped sides, smelling on the right side. At the same time, the lock was only at the top, on the waist a wide port side abruptly interrupted and formed a broken line, continuing straight down the center. The common edge of the caftan is similar to the stylish kaftan of Aba Wos, the head of the Meghini Yakuts, Jorgo Idelgyeva [10 pp. 115]. R.S. Gavrilyeva referred to the East Asian type of the Yakut and found similar elements with Mongolian and Manchurian shoulder clothes [11 pp. 16-17]. The upper part of the caftan was fastened on copper buttons, and at the belt on a lock of mammoth tusk type «togle» or «crutch». The clasp consists of two elements: a ring and a T-pin. The ring is capelin in section, the diameter of the outer side is $6.4 \mathrm{~cm}$, and the diameter of the inner side is $3.8 \mathrm{~cm}$. The pin has a stylized shape with a short base foot and slightly arched shoulders, the end of which is shaped like the heads of a horse. The height is $1.2 \mathrm{~cm}$; the length is $5.6 \mathrm{~cm}$. This type of clasp has not been seen before and requires further study.

\subsection{The staff heads}

Staffs are rarely found in Yakut burials and, according to anthropological data, their presence in a burial is related to the problems of the musculoskeletal system of the buried. The staff were made of wood, sometimes composite: a wooden base with a bone plate. Two burials known from field reports were found with mammoth tusk heads. In the first case, the article was found in the burial ground of Prince Boltoru Yraev in the burial ground of Onogoschut Unuoga, Upper Vilnius district, N.D. Arhipov. A wooden staff with a head from mammoth tusk was laid on the right side of the grave. There is no further detail on the plaque in the report, apart from the fact that it is decorated with longitudinal straight cuts [12]. A second copy was found in one of the women's aerial graves on Batyyalah (an influx of the $r$. Olenek), but apart from the mention in the newspaper 
article there is no more detailed information about the object [13].

\subsection{Spoons}

The accompanying material often includes dishes and utensils, funeral repast. Individual bone spoons and wooden spoons are often placed in low wide vessels or in travel bags. Sometimes spoons are made with special covers, which usually refers to imported metal spoons. Spoons were most often made of wood, less often bone. Spoons from mammoth tusk are only recorded in two cases and both in the Olenek Valley. The first spoon was discovered by H.V. Xenophontov in a ground male burial [1 pp. 277, para. 11]. The spoon was placed inside a wooden bowl laid to the right at the feet of the buried man. Another spoon was discovered in the aerial burial of the Yakut republican branch All-Russian Society for the Protection of Monuments of History and Culture (these letters in Romanized form are YaRO VOOPIK) [12]. Among the many iron tools, fragments of sheet iron and religious objects was a spoon of mammoth tusk with 4 grooves on the handle. The end of the handle is decorated with two parallel recesses, where two miniature bumps» [12] are formed. Based on the specifics of the accompanying inventory, A.N. Kopirin believed that the buried one could be a blacksmith. Unfortunately, both spoons did not survive in the museum collections [14].

\subsection{Sticks}

Two mammoth bone sticks, found in the rich grave of the legendary virgin deity Bolugur Ayyith by an expedition of the Yakut Museum under the leadership of S.I. Bolo in the Churapchin region, remain as items of unclear use. This is how the sticks are described in the grave-opening protocol: They are reminiscent of Korean or Chinese food sticks, but considerably thicker than them. The bottom of the stick is thicker than a normal student pencil. The opposite end of the stick is gradually tapered, semi-concave. Both round, length $22 \mathrm{~cm} »$ [15]. Sticks were found at the right elbow, next to a knife with pearl inlay. No photographs or drawings have survived, nor have they been found among museum objects. Were they imported or made by local craftsmen - question remains open.

\section{Discussion}

\subsection{The emergence of mammoth mining and carvings}

Mammoth bone began to appear in Western European markets as an equivalent of ivory from 17 to 17 . [16]. In the 18th and 19th centuries. Russia was one of the main suppliers of tusks, which was connected with industrial development of new bone areas, especially in Yakutia. There are two views on the expansion of mammoth mining in the territory of Yakutia. According to the first position, the extraction of mammoth tusk and tusk carvings existed before the arrival of Russian explorers [17 p. 61; 3 p. 9]. And the other one says that these phenomena were caused by acquaintance with the Russian bone marrow case, in particular the holmogor carving [18 pp. 156; 5 pp. 8]. Let us look at these positions in more detail.

According to researchers of different times, the fact that mammoth mining was known to the Yakuts before the arrival of Russian explorers is supported by documents 17 th century. Thus, N. Vereshaghin cited data of Smolensk voivode Musin-Pushkin of 1685 on the islands of the mouth of the Lena, where the locals hunted the walrus to hunt and sell its fangs [19 pp. 36]. H. Vereshhagin here combined the hunt for walrus tusks and mammoth tusks and anticipated the existence of this hunt even before the arrival of the Arctic explorers. Also quoted is a document according to which on June 1, 1652, the Yakut Voivode Mikhail Ladyshevsky was sent a letter «About gathering mammoth bones on the banks of the North Ocean» [20 pp. 19]. It should be noted that the documents refer to the time after the arrival of Russian explorers in the territory of Yakutia and cannot serve as solid evidence in support of this assumption. N.A. Alexeyev believed that bone products had similar motifs to wood carving, which had long been a wellknown art of the Yakuts. In his opinion, the Yakuts knew the bone-cutting craft before the arrival of the Russians and northern peoples of the basin of the middle current of the river Lena widely used mammoth bone in household in 17 th century, because they did not know iron [17 p. 61].

However, a more common view is that the mammoth bone has become one of the trades of the peoples of the North with the appearance of Russian immigrants in 17th century. S. Shelekhov in his work mentions that the mining of mammoth bones began in the second half of XVII century [21 pp. 24]. According to D.N. Anouchin, the mammoth bone had been mined in Siberia by 17 th and by the second half of 18th centuries; bone carving was widespread [22 pp. 8]. S.V. Ivanov, M.A. Sergeyev assumed that among the Russian immigrants were bonecutting craftsmen who brought this craft to Yakutia [18 pp. 156]. According to V.H. Ivanov and L.I. Yakunina, the extraction of mammoth bone in Yakutia became a target of fishing only in the 18th century, and until the mid-1670s. Mammoth bone was not mined and traded in Russia on the whole [23 p. 14; 3 p. 7]. Having considered the data of written sources, archaeological excavations and information about the mining of mammoth bone, V.H. Ivanov came to the conclusion that the time of emergence of bone-cutting art in Yakutia is the 18 th century [23 pp. 13-15].

The same opinion is shared by art critic Z.I. IvanovaUnarova, highlighting stylistic features of Yakut craftsmen in decorative design of products and in material processing techniques [24]. The study of Yakutia's bone-cutting case of the 18th century is based on Yakut's work of mammoth bone from the collection of the State Historical Museum: the bilateral combs, the 1764 class and the 1799 Casquet-Teremok. The 1743 comb in the center depicts lions with human faces and a unicorn surrounded by plant ornaments. Such a story is 
more common among Holmogor masters of the early 18 th century. This is due to the fact that the main customers of mammoth bone products were wealthy segments of the urban population, especially visitors from Central Russia. On the watch stand (podchasnik) of 1764 you can see the plot of shaman's camlania, on the top there is a heart pierced with arrow, which was also characteristic of North Russian cutters. About the same item V.H. Ivanov wrote that the watch stand can already be considered as an independent work of the Yakut bone carver, while the Yakut master imitated the Khomogorsk Kostorores in the manufacture of the 1743 comb. In most of the works of this time, the substance prevails over decorative processing, which also distinguishes the Yakut masters from the Holmogor masters. The products are schematic, have simplified forms, are characterized by their brevity and strict decorative design [23 pp. 1618]. In addition, immigrants from Russia representatives of the authorities, industrialists, merchants, exiles - brought with them products made of bone of Russian cutters, which contributed to the rapid development of bone-cutting art in Yakutia. The movement of artistic carvings from tusks was most likely developed in the urban environment - the place of the intersection of cultures and development of trade.

\subsection{Cost of raw materials}

It is known that mammoth bone mining in the territory of Yakutia was mainly carried out in the Verkhoyansk and Kolyma districts, from where it was exported in unprocessed form to Yakutsk, and then to other cities and countries. Unfortunately, we do not have data on the value of mammoth bone products in the 18th century, but information on the value of raw materials has been preserved. So in the yasak book we find the following: the residue of the year 726 tithe payment collection - ... > 2 poods of mammoth bone in sutunkas - 2 roubles; sent with Osipa Ushnitsky and comrades the part not yet paid in Irkutsk - to give - 6 pounds of walrus bone and 7 pounds of mammoth bone - 1 rub. 25 cop. to Aleksey Zinoviev and comrades not yet paid in Irkutsk - 27 pounds of mammoth bone - 50 cop.» [25 s. 57]. In 1799, Tunguska merchant Osip Shumakov, while searching for the bones of a mammoth, discovered a corpse. He sold the tusks of this mammoth for 50 roubles, each weight was about 6 poods, in 1803 to the merchant Roman Boltunov, who sold them in turn to merchants going to Moscow for 21 roubles per pood [22 pp. 11].

The attitude to the mammoth of the local population. According to the Yakuts (like many other northern peoples), the mammoth was associated with the underground world [26] and considered to be the spiritmaster of the water. The Yakuts envisioned him as a bull with huge horns and gradually transformed his image into a cold ox with the breath of which comes winter. In the Yakut society, the image of the winter bull and its taboo activities are still alive. In some places it is forbidden to watch the ice drift, as the river is freed from the ice, the souls of the dead are released in winter and, together with the ice and parts of the body, the cold ox carries them to the Arctic Ocean [27]. Mammoths were thought to live permanently underground, and coming out of the ground, smelling the air, immediately died [28 pp. 110]. Similar representations were made in the course of Hunts, Samoyeds, Yakuts, Evenks, in areas where most of the remains of mammoths are found. For example, in 1799, during mammoth bone mining, one of the Evenks discovered a mammoth carcase. When he told the house, they reacted with fear and said that the beast had already shown up in the same place and that the entire family of the Evenk who found it died shortly after [22 pp. 9-11]. According to the same text, the Evenki, on the other hand, tried to hide the corpses of mammoths for fear that the officials would come to them and force them to work, transport these corpses for hundreds of miles on the reindeer, and the local could lose a large number of reindeer [22 c. 11]. In the Chukchi extracting of mammoth bone was banned, despite the high cost. It was believed that the person who found the bone of the mammoth «should pay the ransom to the «spirit», having made some sacrifice [29 pp. 38]. Thus, at the end of the 17th and 18th centuries, the peoples of Siberia, including the Yakuts, had representations of a mammoth of a religious nature, explaining the origin of tusks.

\section{Conclusion}

The following conclusions can be drawn from the study. Due to industrial exploitation of the northern territories of Yakutia, the extraction of mammoth tusk became one of the traditional crafts of the Yakutia peoples by the 18th century. The above data indicate that mammoth tusk products were very rarely encountered in the context of Yakut burial monuments. It is not possible to speak of the variety of objects made of tusks. This may indicate that up to the end of the 18th century, mammoth tusk products were not widely used within Yakut society. This could be due to the negative connotation of the mammoth in the religious beliefs of the Yakutia peoples.

The objects found in the Yakut burials are substantially different from the works of the Yakut masters from the collection of the State Historical Museum of the same period. In our opinion, this shows the existence of two movements of mammoth tusk carving in the 18th century. The first is based on traditions and techniques of local carvings on bone and wood and has an original character. Local craftsmen produced household items for the local population. The second direction should be designated as the nascent bone-cutting art based on imitation of the northern Russian school. Masters of this direction created artistic works in European style and gradually developed their own style.

\section{References}

1. R.I. Bravina, V.V. Popov, Funeral and memorial rites of the Yakuts: monuments and traditions (15-19th centuries). (Nauka, Novosibirsk, 2008). (in Russian). 
2. N.I. Gagen-Torn, Women's clothing of the peoples of the Volga region. Materials for ethnogenesis. (Chuvashskoe gosudarstvennoe izdatel'stvo, Cheboksary, 1960) (in Russian).

3. E. Kryubezi, A. Alekseev, Eds., The world of ancient Yakuts: the experience of interdisciplinary research (based on materials of the Sakha-French archaeological expedition (Izdatel'skij dom SVFU, Yakutsk, 2012) (in Russian).

4. A.P. Okladnikov, Lena antiquities 1. (Izd-vo AN SSSR, Yakutsk, 1945) (in Russian).

5. R.I. Bravina, N.D. Archipov, Funeral monuments of population of the pool of the Olenek river Yakutia (1719th centuries) Echoes of an Arctic Odyssey: the fate of ethnic cultures in the research of Northern scientists. Collection of materials of the All-Russian scientific and Practical conference with international participation, 85-91 (2019) (in Russian).

6. A.N. Alekseev, The first Russian settlements of the 17-19 ${ }^{\text {th }}$ centuries in the north-east of Yakutia (Nauka, Novosibirsk, 1996) (in Russian).

7. I.V. Balyunov, Vestnik NGU. Seriya: Istoriya, filologiya, Novosibirsk, 15, 149-157 (2016) (in Russian).

8. Yakut fairy tales. Saha ostuorujalara, (Yakutskoe knizhnoe izdatel'stvo, Yakutsk, 1967) (in Russian).

9. A.V. Shapovalov, Tobacco and smoking pipes in Siberia in the 17-18th centuries (according to archaeological sources) (Omsk, 1999) (in Russian).

10. M.M. Nosov, Clothes and jewelry of the Yakuts of the 17th-18th centuries (YAkutsk, 1, 1955) (in Russian).

11. R.S. Gavril'eva, Clothing of the Sakha people of the late 17th-18th centuries (Nauka. Sib. predpriyatie RAN, Novosibirsk, 1998) (in Russian).

12. N.D. Arhipov, Report on the work of the archaeological and ethnographic squad of YSU in the summer of 1967 NOA IA RAN. F.1. R.1. Op. 1. D. 4255. (in Russian).

13. N. Arhipov, In the Land of Yuryan Hosuun 2 (1985) (in Russian).

14. A.N. Kopyrin, Report of the archaeological and ethnographic expedition of the Yakut republican branch of All-Russian Society for the Protection of Historical and Cultural Monuments for 1980 NOA IA RAN. F.1. R.1. Op. 1. D. 8608. (in Russian).

15. Protokol No.1. Description of items from the burial of a yakut women "Bolugur Ajyyta", NA RS(YA). F. 1407. Op.1. D. 38. (in Russian).

16. I.M. Potravnyj, A.V. Protopopov, V.V. Gassij, Arktika: ekologiya i ekonomika, 1(37), 109-121 (2020) (in Russian).

17. N.A. Alekseev, Overview of the development of Yakut bone carving (YAkutsk, 1966) (in Russian).

18. S.V. Ivanov, M.A. Sergeev, Sibirskie ogni, 4, 155168 (1956) (in Russian).

19. N.K. Vereshchagin, Why did mammoths become extinct, (Nauka, Leningrad, 1979) (in Russian).
20. V.L. Priklonskij, Sibirskij sborni, 1, 24 (1893) (in Russian).

21. S. Shelekhov, About the beginning of the development of the Siberian trade (Avgusta Semena, Moskva, 1846) (in Russian).

22. D.N. Anuchin, About the restoration of a mammoth for an Anthropological exhibition (Lavrova, Moskva, 1879) (in Russian).

23. V.H. Ivanov, Yakut bone carving (Nauka, Moskva, 1979) (in Russian).

24. Z.I. Ivanova-Unarova, Izobrazitel'noe iskusstvo Urala, Sibiri i Dal'nego Vostoka, 1, 122-133 (2019) (in Russian).

25. Acts of the archives of the Yakut region: ( s $1650 \mathrm{~g}$. do 1800 g.) Izvestiya YAkutskoj Oblastnoj uchenoj Arhivnoj Komissii ; 1(1) (1916) (in Russian)

26. A.R. Fedorova, A.A. Sleptsova, CHelovek i kul'tura, 6, 164 - 170 (2019) (in Russian).

27. A. Prokop'eva, Field materials of the author. (2014) 28. I. Ides, A Brand, Notes on the Russian Embassy in China (1692-1695, (Glavnaya redakciya vostochnoj literatury izdatel'stva, Moskva, 1967) (in Russian).

29. V.G. Bogoraz, Chukchi (Leningrad, 1939) (in Russian) 